REGARDS

SUR L'ECONOMIE ALLEMANDE

BULLETIN ECONOMIQUE DU CIRAC
Regards sur l'économie allemande

Bulletin économique du CIRAC

118-119| 2015

Varia

\title{
Economie française
}

DANIEL Jean-Marc, Le gâchis français. 40 ans de mensonges économiques ; L'économie française. Comptes et dossiers. Edition 2015. Rapport sur les comptes de la nation 2014

\section{Isabelle Bourgeois}

\section{OpenEdition}

\section{Journals}

Édition électronique

URL : http://journals.openedition.org/rea/4916

DOI : 10.4000/rea.4916

ISSN : 1965-0787

Éditeur

CIRAC

Édition imprimée

Date de publication : 31 décembre 2015

Pagination : 45

ISSN : 1156-8992

Référence électronique

Isabelle Bourgeois, « Economie française », Regards sur l'économie allemande [En ligne], 118-119|

décembre 2015, mis en ligne le 31 décembre 2015, consulté le 25 septembre 2020. URL : http:// journals.openedition.org/rea/4916 ; DOI : https://doi.org/10.4000/rea.4916

Ce document a été généré automatiquement le 25 septembre 2020.

(C) CIRAC 


\section{Economie française}

DANIEL Jean-Marc, Le gâchis français. 40 ans de mensonges économiques ; L'économie française. Comptes et dossiers. Edition 2015. Rapport sur les comptes de la nation 2014

\section{Isabelle Bourgeois}

\section{RÉFÉRENCE}

DANIEL Jean-Marc, Le gâchis français. 40 ans de mensonges économiques, Editions Tallandier, Paris, 2015, $270 \mathrm{p}$.

L'économie française. Comptes et dossiers. Edition 2015. Rapport sur les comptes de la nation 2014, INSEE, Paris, 2015, 168 p.

1 Les rapports de l'INSEE sur les comptes de la nation sont toujours une précieuse source d'information sur l'état de l'économie au cours de l'année écoulée. On y trouve aussi bien une vision d'ensemble de la conjoncture du pays dans son contexte européen que de brefs dossiers thématiques (par ex. sur les performances comparées des entreprises françaises sur le marché domestique et étranger) ou 21 fiches thématiques allant de l'emploi aux indicateurs de développement durable en passant par les " relations avec le reste $d u$ monde » ou le patrimoine national. Et, bien entendu, tableaux de référence et chronologie ne sauraient manquer. L'essai de Jean-Marc Daniel est d'une tout autre facture. Chiffres à l'appui, il analyse 40 ans de politiques économiques françaises qui, de par une lecture réductrice du keynésianisme et les erreurs commises de ce fait, ainsi que par un anti-européanisme profond que la signature officielle des traités ne parvient guère à masquer, ont plongé la France dans le déclin. La «crise » n'est pas celle de la finance mondiale ou de l'euro, elle est le fruit d'une politique continue d'incohérences accumulées - "quel gâchis!», regrette l'auteur. Mais Jean-Marc Daniel n'a rien d'un « déclinologue ». Sa critique est constructive. 